\title{
Sex Differences in Adult Cerebral Venous Sinus Thrombosis: A 10-Year Experience
}

\author{
Claire Hinnell, Janel Nadeau, Vanessa Lam, Michael D. Hill, Shelagh B. Coutts
}

\begin{abstract}
Background: Sex differences in the risk factors, presentation and outcome of cerebral venous sinus thrombosis (CVST) are poorly defined, despite a discrepant prevalence between males and females. The proportion of patients on hormonal therapy who develop CVST varies widely. We describe the clinical features, risk factors and outcome by sex and by hormone-related risk factors among a large cohort of patients. Methods: We reviewed records of 108 consecutive patients with CVST at a tertiary hospital in Calgary between 1999 and 2009. Descriptive statistics were used for between group comparisons (men, women with hormone-related risk factors and women without hormone-related risk factors). Results: Females made up $62 \%$ of patients, half of whom were on systemic hormonal therapy. Men and women without hormonal risk factors were older at onset. Oral contraceptive use was the major risk factor in women $(45 \%)$ while concurrent mastoiditis was the most common predisposing factor in men (27\%). Complications were frequent and overall mortality was $6 \%$. Persisting deficits at discharge were more common in men (54\% vs. $35 \%$ and $32 \%, p=0.036)$. There was a trend for women with hormone-related risk factors to have less residual focal neurologic deficit than the other groups $(5 \%$ vs. $15 \%$ and $17 \%$, $\mathrm{p}=0.051$ ). Conclusions: There are differences between sexes in the presentation, risk factors and outcome of patients with CVST.
\end{abstract}

RÉSUMÉ: Différences liées au sexe chez les cas de thrombose de sinus veineux cérébraux : 10 ans d'expérience. Contexte : Les différences entre les hommes et les femmes quant aux facteurs de risque, au tableau clinique et à l'issue chez les cas de thrombose de sinus veineux cérébraux (TSVC) sont mal définies malgré une prévalence différente chez les deux sexes. La proportion de patientes sous hormonothérapie qui présentent une TSVC varie énormément. Nous décrivons les caractéristiques cliniques, les facteurs de risque et l'issue par sexe et facteurs de risque reliés à l'hormonothérapie dans une grande cohorte de patients. Méthode : Nous avons révisé les dossiers de 108 patients consécutifs ayant consulté dans un hôpital de soins tertiaires de Calgary pour une TSVC entre 1999 et 2009. Nous avons comparé les groupes au moyen de méthodes statistiques descriptives (hommes, femmes avec facteurs de risque reliés à l'hormonothérapie et femmes sans facteurs de risque reliés à l'hormonothérapie). Résultats : Soixante-deux pour cent des patients étaient des femmes, dont la moitié étaient sous hormonothérapie générale. Les hommes et les femmes sans facteurs de risque hormonaux étaient plus âgés au moment de l'événement. L'utilisation de contraceptifs oraux était le facteur de risque le plus important chez les femmes (45\%) alors que la présence d'une mastoïdite était le facteur prédisposant le plus fréquent chez les hommes (27\%). Les complications étaient fréquentes et la mortalité globale était de $6 \%$. Les séquelles au moment du congé hospitalier étaient plus fréquentes chez les hommes $(54 \%$ vs $35 \%$ et $32 \%$, $\mathrm{p}=0,036)$. Le groupe des femmes qui avaient des facteurs de risque reliés à la prise d'hormones avait tendance à présenter moins de séquelles neurologiques focales que les autres groupes ( $5 \%$ vs $15 \%$ et $17 \%, \mathrm{p}=0,051)$. Conclusions : Il existe des différences entre les sexes quant au tableau clinique, aux facteurs de risque et à l'issue chez les patients qui présentent une TSVC.

Can. J. Neurol. Sci. 2012; 39: 74-77

Cerebral venous sinus thrombosis (CVST) is the least common stroke type but carries significant mortality and morbidity. Although the general impact of stroke is greater in women, differences between sexes have rarely been examined systematically and many questions about etiology, presentation and outcome of stroke in women remain ${ }^{1,2}$. In a prospective study on CVST, $75 \%$ of patients were women, and they were significantly younger, had headache more often at presentation and had a better prognosis than men ${ }^{1}$. While the use of hormonal therapy has been identified as a major risk factor for CVST in women $^{3-5}$, other risk factors for CVST are less well defined, and the proportion of patients on hormonal therapy who develop CVST varies widely across studies. To determine sex and hormone-related differences in clinical features, risk factors, treatment and outcome in patients with CVST, we analyzed a large cohort of consecutive cases at a tertiary neurology centre.

\section{METHODS}

We used administrative data to search the Foothills Medical Centre patient database between April 1, 1999 and December 31, 2009 for patient charts coded with CVST and searched the prospectively collected stroke unit database for cases of CVST. The Foothills Medical Centre provides tertiary care stroke and neurological care to a referral population of approximately 1.5

From the Departments of Clinical Neuroscience (CH, JN, VL, MDH, SBC), Medicine (MDH), and Community Health Sciences (MDH), Hotchkiss Brain Institute (MDH, SBC), University of Calgary, Calgary, Alberta, Canada.

Received July 18, 2011. Final Revisions Submitted August 30, 2011. Correspondence to: S. B. Coutts, Foothills Medical Centre, 1403-29th Street NW, Calgary, Alberta, T2N 2T9, Canada. 
million people. Stroke care is centralized and a large majority of CVST patients are admitted to the stroke neurology service. Charts were reviewed by two abstractors to identify time to presentation and diagnosis, presenting symptoms, risk factors for CVST, treatment received and outcome. Outcome was assessed at the time of last assessment, which was either on discharge from hospital, or at follow up appointment in clinic. We compared men to women with and without hormone-related risk factors. Hormone-related risk factors included use of systemic hormonal contraception, use of other hormonal therapy, pregnancy and the puerparium. Ethics approval was obtained from the Foothills Medical Centre institutional review board. Descriptive statistics were used to summarize characteristics of the identified cohort.

\section{RESULTS}

Hormone-related risk factors, obesity, infection and thrombophilias were the most common risk factors (Table 1). Hormone-related risk factors were seen in most of the women younger than 40 years-of-age. Of the 44 women with hormonerelated risk factors, 30 were on oral contraceptive pills, 11 were pregnant or in the peripartum period and six were on other hormone therapies. Infection was the most common predisposing factor in men and men were significantly more likely to have a primary thrombophilia or recent head and neck trauma. Women without hormone-related risk factors were significantly more likely to have a systemic inflammatory disorder. Sixty-two percent of patients had greater than one predisposing factor while $10 \%$ had no identifiable cause.
Table 1: Risk factors for cerebral venous sinus thrombosis

\begin{tabular}{|c|c|c|c|c|c|c|c|}
\hline \multirow[t]{2}{*}{ CHARACTERISTICS } & \multicolumn{2}{|c|}{ MALES } & \multicolumn{2}{|c|}{$\begin{array}{l}\text { FEMALES without } \\
\text { hormone-related } \\
\text { risk factors }\end{array}$} & \multicolumn{2}{|c|}{$\begin{array}{l}\text { FEMALES with } \\
\text { hormone-related } \\
\text { risk factors }\end{array}$} & \multirow[t]{2}{*}{$\begin{array}{c}\text { Fisher's } \\
\text { exact }\end{array}$} \\
\hline & \# & $\%$ & $\#$ & $\%$ & $\#$ & $\%$ & \\
\hline Total Patients (108) & 41 & $38 \%$ & 23 & $21 \%$ & 44 & $41 \%$ & \\
\hline Age $\geq 40$ & 27 & $66 \%$ & 14 & $61 \%$ & 10 & $23 \%$ & $<0.001^{*}$ \\
\hline Obesity & 7 & $17 \%$ & 8 & $35 \%$ & 15 & $34 \%$ & 0.396 \\
\hline Concurrent mastoiditis & 11 & $27 \%$ & 3 & $13 \%$ & 5 & $11 \%$ & 0.153 \\
\hline Mastoiditis within last 3 mo & 2 & $5 \%$ & 2 & $9 \%$ & 1 & $2 \%$ & 0.165 \\
\hline $\begin{array}{l}\text { Concurrent other head and } \\
\text { neck infection }\end{array}$ & 1 & $2 \%$ & 1 & $4 \%$ & 1 & $2 \%$ & 0.554 \\
\hline $\begin{array}{l}\text { Concurrent } \\
\text { meningitis/encephalitis }\end{array}$ & 3 & $7 \%$ & 2 & $9 \%$ & 0 & $0 \%$ & 0.071 \\
\hline $\begin{array}{l}\text { Meningitis/encephalitis in last } 3 \\
\text { mo }\end{array}$ & 1 & $2 \%$ & 0 & $0 \%$ & 0 & $0 \%$ & 0.165 \\
\hline Concurrent URTI & 6 & $15 \%$ & 2 & $9 \%$ & 4 & $9 \%$ & 0.412 \\
\hline URTI in last 3 mo & 0 & $0 \%$ & 1 & $4 \%$ & 1 & $2 \%$ & 0.436 \\
\hline $\begin{array}{l}\text { Head and neck trauma in last } 3 \\
\text { mo }\end{array}$ & 5 & $12 \%$ & 0 & $0 \%$ & 0 & $0 \%$ & $0.038^{*}$ \\
\hline Major surgery in last 3 mo & 2 & $5 \%$ & 2 & $9 \%$ & 0 & $0 \%$ & 0.060 \\
\hline Thrombophilia & 15 & $37 \%$ & 3 & $13 \%$ & 8 & $18 \%$ & $0.012^{*}$ \\
\hline Primary thrombophilia & 8 & $20 \%$ & 0 & $0 \%$ & 4 & $9 \%$ & $0.027^{*}$ \\
\hline $\begin{array}{l}\text { Systemic inflammatory } \\
\text { disorder }\end{array}$ & 1 & $2 \%$ & 6 & $26 \%$ & 7 & $16 \%$ & $0.030^{*}$ \\
\hline History of malignancy & 5 & $12 \%$ & 4 & $17 \%$ & 0 & $0 \%$ & $0.009^{*}$ \\
\hline Current smoker & 4 & $10 \%$ & 0 & $0 \%$ & 2 & $5 \%$ & 0.404 \\
\hline
\end{tabular}

* statistical significance at the 0.05 level. URTI $=$ upper respiratory tract infection. Primary thrombophilia includes: vonWillebrand's disease, factor V Leiden, prothrombin gene mutation, antithrombin gene mutation, protein $\mathrm{C}$ deficiency, protein $\mathrm{S}$ deficiency, sickle cell disease, high factor VIII levels, high factor VII, IX, $\mathrm{XI}$ levels and high fibrinogen levels. Thrombophilia includes the primary thrombophilias as well as hyperlipidemia, hyperhomocysteinemia, nephrotic syndrome, antiphospholipid syndrome, lupus anticoagulant antibody and thrombotic

thrombocytopenic purpura. Systemic inflammatory disorder includes: vasculitis, connective tissue disease, sarcoidosis and inflammatory bowel disease.

Note: Numbers reflect a positive indication in the chart that risk factors were present. Where there was no definitive documentation of a given factor, it was assumed to be absent. 


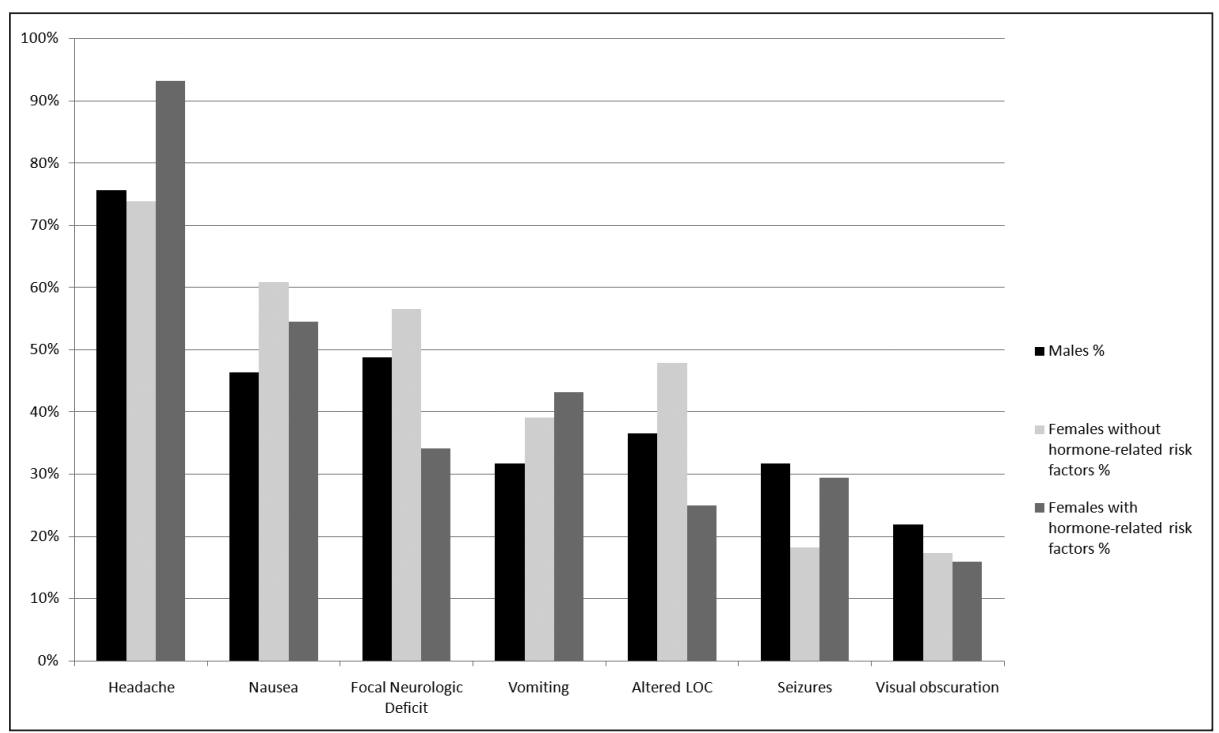

Figure: Frequency of clinical features at time of presentation. Percentages are calculated within groups. $L O C=$ level of consciousness.

Median time from symptom onset to hospital admission in the whole cohort was four days: 7 days in men, 3.5 days in women without hormone-related risk factors and 3 days in women with hormone-related risk factors ( $\mathrm{p}=0.51$, Kruskal-Wallis). Diagnosis was delayed for greater than 24 hours following hospital admission in 29\%: $37 \%$ of men, $18 \%$ of women without hormone-related risk factors and $29 \%$ of women with hormonerelated risk factors $(\mathrm{p}=0.37$, Kruskal-Wallis).
The most common presentation among all patients was headache $(82 \%)$, followed by a focal neurologic deficit $(44 \%)$, nausea/vomiting $(38 \%)$, altered level of consciousness $(34 \%)$ and seizures $(27 \%)$ (Figure). The superior sagittal sinus was the most commonly involved venous structure in all patients $(63 \%)$ with no sex difference. Anticoagulation (intravenous heparin, low molecular weight heparin or warfarin) was used in $94 \%$ of the cohort.

Table 2: Complications and outcomes measured at last follow-up.

\begin{tabular}{lccccccc}
\hline CHARACTERISTICS & \multicolumn{2}{c}{ MALES } & \multicolumn{2}{c}{$\begin{array}{c}\text { FEMALES without } \\
\text { hormone-related } \\
\text { risk factors }\end{array}$} & $\begin{array}{c}\text { FEMALES with } \\
\text { hormone-related } \\
\text { risk factors }\end{array}$ & $\begin{array}{l}\text { Fisher's } \\
\text { exact }\end{array}$ \\
\hline & $\#$ & $\%$ & $\#$ & $\%$ & $\#$ & $\%$ \\
\hline COMPLICATIONS & & & & & & & \\
\hline Death & 2 & $5 \%$ & 4 & $17 \%$ & 1 & $2 \%$ & 0.071 \\
\hline Venous infarction & 11 & $27 \%$ & 11 & $48 \%$ & 12 & $27 \%$ & 0.196 \\
\hline Intracranial hemorrhage & 14 & $34 \%$ & 10 & $43 \%$ & 10 & $23 \%$ & 0.221 \\
\hline $\begin{array}{l}\text { Subarachnoid } \\
\text { hemorrhage }\end{array}$ & 5 & $12 \%$ & 4 & $17 \%$ & 9 & $20 \%$ & 0.701 \\
\hline RESIDUAL DEFICITS & & & & & & & \\
\hline Any residual deficit & 21 & $54 \%$ & 8 & $35 \%$ & 14 & $32 \%$ & $\mathbf{0 . 0 3 6 *}$ \\
\hline Visual deficit & 10 & $24 \%$ & 3 & $13 \%$ & 3 & $7 \%$ & 0.051 \\
\hline Cognitive Deficit & 5 & $12 \%$ & 4 & $17 \%$ & 4 & $9 \%$ & 0.210 \\
\hline Recurrent seizure(s) & 8 & $20 \%$ & 2 & $9 \%$ & 8 & $18 \%$ & 0.531 \\
\hline Focal neurologic deficit & 6 & $15 \%$ & 4 & $17 \%$ & 2 & $5 \%$ & 0.051 \\
\hline Language deficit & 4 & $10 \%$ & 2 & $9 \%$ & 3 & $7 \%$ & 0.508 \\
\hline
\end{tabular}

* statistical significance at the 0.05 level. Note: Numbers reflect a positive indication in the chart that outcomes were present. Where there was no definitive documentation of a given outcome, it was assumed to be absent. The residual deficits were rated at the time of the last assessment. This varied from the time of discharge from hospital to the time of out patient follow up (51\%) depending on the patient. 
Overall mortality was 6\% (Table 2). Complications were frequent, particularly among women without hormone-related risk factors; the most common were venous infarction, intracranial hemorrhage and subarachnoid hemorrhage. Of survivors, a persisting deficit lasting until discharge was more common in men (54\% vs. $35 \%$ and $32 \%, \mathrm{p}=0.036)$. There was a trend for women with hormone-related risk factors to have less residual focal neurologic deficit than the other groups (5\% vs. $15 \%$ and $17 \%, \mathrm{p}=0.051$ ).

\section{DisCUSSION}

Our study demonstrates important sex differences in CVST as well as differences between women with and women without hormone-related risk factors. Our results confirm that the sex predominance is most evident in younger women and is minimized in the older population ${ }^{1,6-8}$. Risk factors differ between sexes, knowledge of which may improve diagnosis. A large proportion of women have hormone-related risk factors, consistent with existing literature ${ }^{1,9}$. Thrombophilia and recent head and neck trauma are important predisposing risk factors in men.

Consistent with the literature, the most common presentation among all patients is headache $e^{1,7,10,11}$. We found no statistical differences in the presentations between the different groups. Although our results require confirmation, they highlight the need to consider CVST in patients with a variety of neurologic signs.

Although the randomized trial evidence is far from convincing ${ }^{12-14}$, the consensus in the stroke field is that anticoagulation is the appropriate treatment; nearly all patients in our cohort, irrespective of sex, were treated with anticoagulation, suggesting that this treatment is now considered standard of care ${ }^{10}$.

Mortality in patients with CVST remains significant ${ }^{1,10,15}$. Coutinho et $\mathrm{al}^{1}$ found that men had a higher mortality rate than women, the difference being exclusively caused by better outcome in women with hormone-related risk factors. The higher mortality in men is likely due to the fact that the diagnosis is delayed. We found a trend to higher mortality rate in women without hormone-related risk factors, perhaps due to older age, greater involvement of the deep venous system and higher complication rates. Sex differences in pathophysiology require further study. If confirmed elsewhere, the difference in mortality would suggest a need to be more aggressive in diagnosis and management in this population.

Our study's strengths lie in the large cohort representing ten years of experience in one centre and our focus on sex differences in CVST. However, our study has potential limitations including: incomplete case ascertainment, limited follow-up data and the inherent problems of a retrospective chart review including being restricted to the available data.

Further study is required to determine if improved recognition of sex differences in CVST may lead to more timely diagnosis and more favourable outcomes.

\section{ACKNOWLEDGEMENTS}

MDH is funded by the Heart \& Stroke Foundation of Alberta, NWT, NU and by Alberta Innovates Health Solutions. SBC received salary support from the Alberta-Innovates-Health solutions and the Heart and Stroke Foundation of Canada's Distinguished Clinician Scientist award, supported in partnership with the Canadian Institute of Health Research (CIHR), Institute of Circulatory and Respiratory Health and AstraZeneca Canada Inc. VL received funding from the O'Brien Centre for the Bachelor of Health Science at the University of Calgary.

\section{REFERENCES}

1. Coutinho JM, Ferro JM, Canhao P, et al. Cerebral venous and sinus thrombosis in women. Stroke. 2009 Jul;40(7):2356-61.

2. Kurth T, Bousser MG. Stroke in women: an evolving topic. Stroke. 2009 Apr;40(4):1027-8.

3. Bousser MG, Kittner SJ. Oral contraceptives and stroke. Cephalalgia. 2000 Apr;20(3):183-9.

4. de Freitas GR, Bogousslavsky J. Risk factors of cerebral vein and sinus thrombosis. Front Neurol Neurosci. 2008;23:23-54.

5. Dentali F, Crowther M, Ageno W. Thrombophilic abnormalities, oral contraceptives, and risk of cerebral vein thrombosis: a metaanalysis. Blood. 2006 Apr 1;107(7):2766-73.

6. Ferro JM, Canhao P, Bousser MG, Stam J, Barinagarrementeria F. Cerebral vein and dural sinus thrombosis in elderly patients. Stroke. 2005 Sep;36(9):1927-32.

7. Stam J. Thrombosis of the cerebral veins and sinuses. N Engl J Med. 2005 Apr 28;352(17):1791-8.

8. Wasay M, Bakshi R, Bobustuc G, et al. Cerebral venous thrombosis: analysis of a multicenter cohort from the United States. J Stroke Cerebrovasc Dis. 2008 Mar-Apr;17(2):49-54.

9. Rizzo L, Crasto SG, Ruda R, et al. Cerebral venous thrombosis: role of CT, MRI and MRA in the emergency setting. Radiol Med. 2010 Mar;115(2):313-25.

10. Bousser MG, Ferro JM. Cerebral venous thrombosis: an update. Lancet Neurol. 2007 Feb;6(2):162-70.

11. de Bruijn SF, Stam J, Koopman MM, Vandenbroucke JP. Casecontrol study of risk of cerebral sinus thrombosis in oral contraceptive users and in [correction of who are] carriers of hereditary prothrombotic conditions. The Cerebral Venous Sinus Thrombosis Study Group. BMJ. 1998 Feb 21;316(7131):589-92.

12. Coutinho JM, Ferro JM, Canhao P, Barinagarrementeria F, Bousser MG, Stam J. Unfractionated or low-molecular weight heparin for the treatment of cerebral venous thrombosis. Stroke. Nov;41 (11):2575-80.

13. de Bruijn SF, Stam J. Randomized, placebo-controlled trial of anticoagulant treatment with low-molecular-weight heparin for cerebral sinus thrombosis. Stroke. 1999 Mar;30(3):484-8.

14. Stam J, De Bruijn SF, DeVeber G. Anticoagulation for cerebral sinus thrombosis. Cochrane Database Syst Rev. 2002(4): CD002005.

15. Wasay M, Dai AI, Ansari M, Shaikh Z, Roach ES. Cerebral venous sinus thrombosis in children: a multicenter cohort from the United States. J Child Neurol. 2008 Jan;23(1):26-31. 